\title{
GREED IN JEANNE DUPRAU'S NOVEL THE CITY OF EMBER
}

\author{
Wanda Prayoga Ilyas, Purwarno \\ English Department, Faculty of Literature \\ Universitas Islam Sumatera Utara, Medan, Indonesia \\ E-Mail: wanda_ilyas@gmail.com
}

\begin{abstract}
This study is the result of a library research which is qualitative in nature on the greed for power and for food of the antagonist named Cole depicted in Jeanne DuPrau's The City of Ember. Some definitions as well as concept about the antagonist and greed from the various sources are generated in chapter two to bring about the proper arguments and ideas related to the analysis of the topic. The method used in analyzing the data in this paper is Descriptive Qualitative Research in which it is a research method used to acquire and describe accurate, factual, and systematic data. The findings show that Cole, as a mayor in the city of Ember who is supposed to protect his citizens in the city of Ember, has misused his power to dupe his citizens. He convicingly says to the citizens that if they work hard and dedicate their life to the city of Ember, the city will be prosperous. In fact, he speaks so glibly to the citizens for the shake of his own interests that he will not need to work hard anymore to control the city. Mayor Cole is also a very greedy man. So greedy he is that he has ordered two of his trusted workers named Looper and Lizzie Bisco to steal the food supplies from the storeroom and hiden them in a tunnel pipeworks, called the room 351 to be enjoyed by himself. He has overabundance of food while the citizens of Ember are in a crisis of food. Furthermore, the finding of this study shows that Mayor Cole's evil deeds is revealed by Doon and Lina in the long run.
\end{abstract}

Keywords: antagonist, greed, mayor, descriptive qualitative research, library research

\section{Introduction}

The City of Ember is a post-apocalyptic science fiction novel by Jeanne DuPrau that was published in 2003. It is an exciting science fiction adventures for families. It entertains, enlightens, and encourages. It is a thrilling, captivating science fiction adventure with profound incisive lessons. This novel shows that justice triumphs over big governmet and totalitarian liberalism. It also portrays the value of liberty, individual responsibilty, loyalty and other cardinal virtues.

In this paper, greed depicted in Jeanne DuPrau's The City of Ember becomes the focus of the discussion. Greed is actually the excess fondness of money and fortune. It is selfish excessive or uncontrolled desire for possession or pursuit of money, wealth, food, or other possessions, especially when this denies the same goods to others. It can never be satiated. The more a greedy man gets, the more he wants. It constitutes one of the bad manners that draw to various evils and sins. 
Baba Meher (1967) claims that greed is a state of restlessness of the heart, and it consists mainly of craving for power and possessions. Possessions and power are sought for the fulfillment of desires. Man is only partially satisfied in his attempt to have the fulfillment of his desires, and this partial satisfaction fans and increases the flame of craving instead of extinguishing it. Thus greed always finds an endless field of conquest and leaves the man endlessly dissatisfied. The chief expressions of greed are related to the emotional part of man.

Everything about greed, both the reason and purpose is very interesting to discuss. Many people want to know what exactly the reasons and purposes of someone to be greedy since in the real world there are many people who want to have more than what they need and have. Whereas, they have enough in it. That is what actually happens in Jeanne DuPrau's novel entitled The City of Ember. The current mayor of Ember named Mayor Cole is one sketchy dude. For one thing, it is suspicious that he is overweight in a city full of skinny, deprived people. The mayor is a vast, heavy man, so big in the middle that his arms look small and dangling He looks like that since he has been hoarding food and other supplies - chewing down on his own time while his citizens starve.

Mayor Cole, the antagonist of the novel, is a very corrupt character in The City of Ember. His abuse of power and self-serving nature are the epitome of corruption in politics. Part of the reason he is able to exert power over the townspeople is in his ability to spin. When Doon impulsively voices discontent to the Mayor, the politician is able to spin it to his advantage. Mayor Cole operates with duplicity meant to confound the public. This is seen in how the Mayor uses his position of power for his own interests. It is also seen in how he addresses Lina as she challenges his authority. The public is told to trust the political leadership and, as a result, they are more likely to accept the conditions that surround them. This prevents change and questioning authority because resistance is replaced with a benevolent view towards leadership. The Mayor tries to keep the public "in the dark" about the way things are, pacifying them with easy solutions and outright deception. The response to his speech in which the public begins to rebel and express dissatisfaction through disobedience is another form of action that can be taken.

The researchers are interested in this topic because in The City of Ember, Jeanne DuPrau emphasizes how individuals can take action to show discontent and frustration with political authority even in the most politically controlled atmospheres. This topic is a useful reminder about the power of the human spirit to triumph where our own hopelessly broken systems have failed. Besides, this subject matter is also full of moral lessons. It inspires us to be brave to encounter any obstacles in this life, to have responsibility as well as sense of belonging to our land, and to have undefeated wills to fight for the rights and the betterment of the social life.

After perusing Jeanne DuPrau's novel entitled The City of Ember, the researchers find that the antagonist by the name of Mayor Cole is greedy because he has lied to his people and kept the city's resources for himself. He is also a very corrupt character in the novel. He has misused his power for his own interests. The greed of the antagonist covering his greed for food and for power will be analysed in depth so that it is expected to be useful both theoretically and practically. Theoretically, this research will add the information about the kinds and implementation of greed. Besides, this research can be a reference for other researchers who carry out their researches on the same topic or other topics from the same novel. Practically, this research will give 
information to the readers that greed could be harmful to others and most importantly greed is strickly prohibited by any religions and included into one of the major sins.

\section{Literature Review}

In literature, an antagonist is a character, group of characters, or other force that presents an obstacle or is in direct conflict with the protagonist. The antagonist is most often one character who has a goal that opposes the protagonist's goal and will try to stop the protagonist from getting what he or she wants.

According to Karl Beckson and Arthur Ganz (1990: 14), antagonist is the major character in opposition to the hero or the protagonist of a narrative or drama. An antagonist may be a group of characters, institution, or concept that stands in or represents opposition against which the protagonist must contend.

In other words, an antagonist is a person or a group of people who opposes a protagonist. An antagonist is used as a plot device, to set up conflicts, obstacles, or challenges for the protagonist. Though not every story requires an antagonist, it is often used in plays to increase the level of drama. In tragedies, antagonists are often the cause of the protagonist's main problem, or lead a group of characters against the protagonist; in comedies, they are usually responsible for involving the protagonist in comedic situations (https://en.wikipedia.org/wiki/Antagonist).

Greed is a word we hear quite often these days. So, greed problem is nothing new. We certainly have to watch out for the many different kinds of greed. There is greed for power, the drive to have authority and influence over other people and greed for prestige and fame. Greed for material possessions is very commonplace. Almost daily we hear of another scandal on Wall Street or in government where greed for money has driven people to destroy their whole lives. According to Nicola Horlick (2009: 20), greed is a big subject which can at once be seen as disease at the heart of society and motivating force behind the progress of mankind. When a man has the purpose of the materials that he or she wants to have, the ambition to obtain them is enormous and often leads to the greed of human self-control. Erich Fromm (1941), a humanist philosopher, psychoanalyst and social psychologist, claims that greed is a bottomless pit that drains one's energy in endless efforts to meet the need without ever reaching satisfaction; egoism is also viewed as a kind of greed. In his best-selling book, The Art of Loving, Fromm says that a greedy man is the slave of desire or passion, in fact, is a passive activity because it is controlled; the person is a 'patient', not 'actor'. Envy, jealousy, ambition, and all kinds of greed is desire; the opposite of love is an activity or action, a practice human power which can be practiced only in freedom and never as a result of coercion. Greed is also known as "love unnatural in possession" because the desire to have or maintain the worldly goods that deviate from the reasonable size of the usefulness of such goods for survival. Naturally someone wants earthly things limited to the reasonableness of the intended use; but greed is a deviation from fairness. Greed also leads to mortal sin if a person causes it acts contrary to justice or take away the rights of others unjustly. Therefore, greedy people never feel to have enough money and never feel to have satisfied income.

Greed is also pride. It is the desire within us to show the world who we are by our status in life, by our possessions, or by our fame. Greed is a direct result of the pride of life. Greed is contagious. If you are around people who have lots of things and who focus their life on getting more and more things, you'll discover that it is very difficult not to be swept right along into that greedy mindset for things. Greed is cancerous. It 
grows fast, and it consumes and destroys everything it touches. No wonder we must be on our guard against all kinds of greed. To achieve the satisfaction of boundless, sometimes people often forget to be grateful with what he has got. Not feel fulfilled by proprietary, people sometimes take the rights of others to achieve satisfaction without regard for others. Greed enslaves man and causes him grief. A greedy man cares only for collecting fortunes without stopping at any limit. Whenever he achieves a goal, he works for achieving another and, so, he becomes the slave of avidity until death strikes him. He also exerts laborious efforts for collecting riches, but he is the less beneficiary. He tires for gaining fortunes, but death comes unexpectedly upon him to deprive him of enjoying that fortune. The heirs, then, enjoy his fortune very easily. Furthermore, greed takes to the slips of sinful matters that produce problematic situations in the world to come. It also hinders from doing charity. (http://www.ezsoftech.com/stories/mis13.asp)

\section{Research Method}

Polit and Hungler (1999: 155) describe the research design as a blueprint, or outline, for conducting the study in such a way that maximum control will be exercised over factors that could interfere with the validity of the research results. The research design is the writer's overall plan for obtaining answers to the research questions guiding the study. To answer research questions, qualitative research method was applied in this study. Qualitative research method is conducted by studying the organized material in order to discover inherent facts. The fact focused in this study is one of the social diseases; that is greed. Therefore, qualitative descriptive method was appropriately applieed in this research as Setiawan, Barus, and Pawiro (2017) state that in social research, qualitative descriptive method is an appropriate method as it gives detailed points of some social events. Besides, content analysis, inductive analysis, and logical analysis are mostly used in the analysis of qualitative material (Koul, 1984: 1990). Research design deals with a logical problem and not a logistical problem (Yin, 1989: 29). In principle, any research design can use any type of data collection method and can use either quantitative or qualitative data. Furthermore, the study will be presented in a descriptive form.

\section{Discussion}

\subsection{Greed for Power}

In Jeanne DuPrau's novel The City of Ember, Mayor Cole is described as an evil character that makes use his position for his own interests. He is a very corrupt character in the novel. His abuse of power and self-serving nature are the epitome of corruption in politics. He is able to exert power over the townspeople, and it is his ability to twist the things. He operates with duplicity to confound the public. It is seen when he uses his power for his own interests.

In the beginning of the novel, when assignment day comes into Lina Mayfleet, Doon Harrow and the other students in the class, Mayor Cole comes into the class to 
explain something about the assignment day. Mayor Cole comes into the class with annoying face, and hypocrite behavior. He says to the students of Miss Thorn:

"Young people of the Highest Class," the mayor began. He stopped and scanned the room for several moments; his eyes seemed to look out from far back inside his head. He nodded slowly. "Assignment Day now, isn't it? Yes. First we get our education. Then we serve our city." Again his eyes moved back and forth along the rows of students, and again he nodded, as if someone had confirmed what he'd said. He put the little bag on Miss Thorn's desk and rested his hand on it. "What will that service be, eh? Perhaps you're wondering." He did his smile again, and his heavy cheeks folded like drapes (DuPrau, 2003: 6)

The quotation above shows that Mayor Cole is very presumptuous in the city. When speaking, he keeps nodding as if everything around him were nothing, and he despises what has been done by others. He demands the young citizens to serve the city after they have finished their study.

In the same situation on the assignment day, the mayor also gives an impressive speech to attract the young people of the city. It is actually only a manipulative speech, and purposely done by him in order to catch the attention of the young citizens that he is a great mayor, and distinguished in his job.

"Something to remember," the mayor said, holding up one finger. "Job you draw today is for three years. Then, Evaluation. Are you good at your job? Fine. You may keep it. Are you unsatisfactory? Is there a greater need elsewhere? You will be reassigned. It is extremely important," he said, jabbing his finger at the class, "For all... work... of Ember... to be done. To be properly done" (DuPrau, 2003: 8)

The quotation above shows that Mayor Cole is so dexterous to assert the young citizens that they should work and dedicate their life to the city of Ember. He encourages the young citizens of the City of Ember to do and complete their work properly. He also reminds them that if they fail to do it well, they will be reassigned. He speaks so glibly as if he were so care of the city. In fact, what he has done is just for his own interests since he will not need to work hard again if the young citizens of ember have worked hard and dedicated their work for the city.

The mayor speaks so convicingly that almost all the students are duped. However, there is one named Doon Harrow, who does not agree with the Mayor. When Doon displays resentment at being given a worthless job on the Assignment Day, the mayor reacts by glaring at him and saying:

"Disgraceful... A childish display of temper! Students should be glad to work for their city. Ember will prosper if all... citizens... do... their... best" (DuPrau, 2003: 13)

From the quotation above, it can be seen that Mayor Cole is in frenzy to see that Doon does not agree with him. From his words, it can be seen that as if the mayor were a good mayor who had done his best for the city of Ember. In fact, he is only taking from the city rather than giving to it. Worse, he lies to the citizens of Ember about their scary situation. He calls a town meeting after the longest blackout, and spouts some 
nonsense about how solutions are being found and they are making every effort to fix things.

The mayor is so full of hogwash and abuses his power to alleviate all of the workload given to him as a mayor. The citizens sometimes wonder if he even listens to the words coming out of his mouth. When he is talking to Lina after she is brought in for spreading vicious rumors about him, he lectures her sternly.

"The duties of a mayor...are...complex. Cannot be understood by regular citizens, particularly children. That is why...certain things must remain hidden from the public. The public would not understand. The public must have faith...that all is being done for their benefit. For their own good" (DuPrau, 2013: 218)

The quotation above shows that Mayor Cole with all his hogwash trying to convince people to believe in what he says. He assures that the citizens do not feel fooled by what he has done so far for the city of Ember. It is all done by him in order that he can control the city easily.

However, the citizens do not take too long to realize it because they are not too stupid to realize all of the nonsenses that are said by Mayor Cole. The citizens realize that Mayor Cole is actually a big liar, and all he has done is only his ploy to fool them. He always encourages the citizens to do their best for the city and ensures them that what they have done is for the benefits of all the citizens. But in fact, anything done by all the citizens benefit only for the mayor himself since he does not need to do anything more to develop the city of Ember which has already been crumbled.

\subsection{Greed for Food}

Mayor Cole is portrayed as an overweight man in a city full of skinny, deprived people. He is large, plump and distended abdomen. Those characteristics prove that Mayor Cole has eaten too much. He looks like that since he has been hoarding food and other supplies - chowing down on his own time while his citizens starve. As long as he serves as mayor, he has hiden food in a room in the pipe work that none of the residents are aware of the existence of that room. He has overabundance of food while the citizens of Ember are in a crisis of food and nearly all the stock shortages of food. See the following quotation:

The mayor was a vast, heavy man, so big in the middle that his arms looked small and dangling. In one hand he held a little cloth bag. He lumbered to the front of the room and faced the students. His gray, drooping face appeared to be made of something stiffer than ordinary skin; it rarely moved except for making the smile hat was on it now (DuPrau, 2003: 7)

The quotation above shows that the mayor is the one who is big in the middle (his stomach) but his arms look small and dangling. It all proves that the mayor has eaten too much that his stomach is distended. He is overweight, while the other citizens are suffering food shortages.

To make his greed for food fulfilled, the mayor has made use the third party. He orders his trusted friend named Looper to steal and move all the supplies of the food to a room inside the tunnel pipe works, called the room 351. Looper can easily steal the food supplies as ordered by Mayor Cole since he works in the storerooms. However, he 
is not alone to carry out the order. He approaches his girlfriend named Lizzie Bisco, who is also Lina's best friend when she was at the school, who works in the store inventory to cooperate in stealing the food supplies. With the help of Lizzie Bisco, Looper is easier to do what has been ordered by the mayor.

"I saw Lizzie coming out of the storerooms yesterday," Lina said. She told him about the cans, and Lizzie's new friend, Looper, and what Looper was doing. Doon pounded his fist on his leg. "That's two of them doing it, then," he said.

"Wait, there's more. Remember how I thought there was something familiar about the man who came out the door? I've remembered what. It was that way he walked, sort of dipping over sideways, and also that hair, that black hair all unbrushed and sticking out I've seen him twice. I don't know why I didn't remember who it was right away--maybe because I've only seen him from the front.

I took a message for him on my first day." Doon was jiggling with impatience. "Well, who was it, who was it?" "It was Looper. Looper, who works in the storerooms. Lizzie's boyfriend. And Doon--" Lina leaned forward. "It was a message to the mayor that he gave me, and it was this: 'Delivery at eight."' Doon's mouth dropped open. "So that means..." "He's taking things from the storeroom for the mayor. And he's giving some to Lizzie, and selling some in his store."

(DuPrau, 2003: 160)

The quotation above shows that Doon and Lina find out Looper and Lizzie have taken things from the storeroom for the mayor. Lina also remembers that on the first day of the assignment day, she has found a message from the mayor addressed to Looper to steal to food supplies and deliver them to him at eight o'clock. It is also seen that the stealing of the food supplies is not directly done by Mayor Cole. He is in fact the master mind of the action. He makes use Looper and Lizzie to carry out all his plans so that the citizens of Ember do not suspect that he is actually the real evil in the city of Ember.

Mayor Cole's cunning plan begins to uncover when Lina meets Lizzie Bisco who is in a hurry on a street in the city. Lina calls her but she seems not to listens Lina's calling. Lina calls her repeatedly that eventually Lizzie sees Lina. However, Lizzie seems unpleasant to see Lina because she is carrying what has been ordered by Mayor Cole. Since she is not pleased by the situation, she makes an excuse to get a quick exit from that state. Lizzie says to Lina:

"It was busy today at work. Work is so hard, isn't it, Lina? I think work is much harder than school, and not as interesting. Do you do the same thing every day. I get so tired, don't you, running around all day?" (DuPrau, 2003: 145)

The quotation above shows that Lizzie is trying to make an excuse to rush away and leave Lina so that Lina does not know what she is carrying. Since Lizzie is her close frind, Lina is increasingly curious about Lizzie's strange attitude.

Lizzie leaves Lina hastily, but she is tripped by a stone that she falls down. It makes all the goods she is carrying scattered. Lina sees some food supplies 
scttered on the ground. Lina is amazed to see all the foodstuffs which she and other citizens of the Ember think have run out of supply. Then Lina interogates Lizzie:

"You have to tell me where you got those cans? No market would just

forget about things like that. Tell me the truth" (DuPrau, 2003: 149)

The quotation above shows that Lina is interogating Lizzie. Lina's curiosity is increasing as she sees many cans of food that have disappeared for a long time from the city of Ember scattered on the ground before her. Lina begins to suspect Lizzie that Lina asks Lizzie from where Lizzie has got all the foods that she has not seen in the market in the city of Ember.

Being pressed by the questions asked by Lina who repeatedly asks her about the foodstuffs, Lizzie finally reveals everything. She discloses to Lina what she has done with Looper. This following quotation shows how Lizzie uncovers everything she knows:

"Looper explores the storerooms. He goes into every room that isn't locked. He wants to know the true situation, Lina. He's not like most workers, who just plod along doing their jobs and then go home. He wants to find things out."

"And what has he found out?" Lina asked. "He's found out that there's still a little bit left of some rare things, just a few things in rooms here and there that have been forgotten. You know, Lina," she said, "there are so many rooms down there. Some of them, way out at the edges, are marked 'Empty' in the ledger book, and so no one ever goes there anymore. But Looper found out that they're not all empty" (DuPrau, 2003: 150)

This quotation shows that Lizzie explains what really has happened and how Looper has played his role to steal the food supplies. Looper hides all the food supplies in a room located in an empty tunnel. Looper fills the room to store foods that have been stolen as ordered by Mayor Cole. That is the very cause why the citizens of Ember are in a crisis of food and nearly all the stock shortages of food.

Finally, Mayor Cole's evil deed to steal the food supplies is revealed. It happens when Doon is curious about the room that is always locked in the tunnel 351.

So he set out for the south end of the Pipeworks. When he came to the roped-off passage in Tunnel 351, he ducked in and walked along through the dark, feeling his way. He was pretty sure the door would be locked as usual. His mind was on other things. He was thinking of his green worm, which had been heving oddly, refusing to eat and hanging from the side of its box with its chin tucked in. And he was thinking about Lina, whom he hadn't seen for several days. He wandered where she was. When he came to the door, he reached absently for the knob, and what he felt startled him so much that he snatched his hand back as if he'd been stung. He felt again, carefully. There was a key in the lock!

For a long moment, Doon stood as still as a statue. Then he took hold of the doorknob and turned it. Very slowly, he pushed on the door. It swung inward without a sound. He opened it only a few inches, just enough to peer around the edge. What he saw made him gasp. There was no road, or passage, or stairway behind the door. There was a brightly lit room, 
whose size he could not guess at because it was so crowded with things. On all sides were crates and boxes, sacks and bundles and packages. There were mounds of cans, heaps of clothes, rows of jars and bottles, stacks of light-bulb packages. Piles rose to the low ceiling and leaned against the walls, blocking all but a small space in the center. In that small space, a little living room had been set up. There was a greenish rug, and on the rug an armchair and a table. On the table were dishes smeared with the remains of food, and in the armchair facing Doon was a great blob of a person whose head was flopped backward, so that all Doon could see of it was an up thrust chin. The blob stirred and muttered, and Doon, in the second before he stepped back and pulled the door closed, caught a glimpse of a fleshy ear, a slab of gray cheek, and a loose, purplish mouth (DuPrau, 2003: 155-157)

The quotation above shows that Doon who has been all this time intrigued by the mysterious door which is always locked in the tunnel 351 finally opens the door. Doon opens it slowly inch by inch so that it gives no sound. Doon gets very surprised as he sees the room is so crowded with food supplies. On all sides of the room, there are crates and boxes, sacks and bundles, and packages. There are mounds of cans, heaps of clothes, rows of jars and bottles, and stacks of light-bulb packages. Doon finds the room set up so that all the goods are loaded inside. In the room, Doon also sees someone whose characteristics are similar to the Mayor, and Doon is sure that the man is Mayor Cole.

Doon then sees Lina to explain what he has found in tunnel 351. Doon says to Lina:

"The door," he panted. "The door in 351 opened it." Lina's heart leapt. "You did?" Doon nodded. "Is it the way out?" Lina whispered fiercely. "No," Doon said. He glanced behind him. Clutching Lina's arm, he pulled her into a shadowy spot on the street "It doesn't lead out of Ember," he whispered. "It leads to a big room." Lina's face fell. "A room? What's in there?" "Everything. Food, clothes, boxes, cans. Light bulbs, stacks of them. Everything. Piles and piles up to the ceiling." His eyes grew wide. "And someone was there, in the middle of it all, asleep." "Who?" A look of horror passed over Doon's face. "The mayor," he said. "Conked out in a big armchair, with an empty plate in front of him." "The mayor!" Lina whispered. "Yes. The mayor has a secret treasure room in the Pipeworks." They stared at each other, speechless. Then Doon suddenly stamped hard on the pavement. His face flushed red. "That's the solution he keeps telling us about. It's a solution for him, not the rest of us. He gets everything he needs, and we get the leftovers! He doesn't care about the city. All he cares about is his fat stomach!" Lina felt dizzy, as if she'd been hit on the head. "What will we do?" She couldn't think, she was so stunned. "Tell everyone!" said Doon. He was shaking with anger. "Tell the whole city the mayor is robbing us!" (DuPrau, 2003: 158)

The quotation above shows that Doon explains to Lina what he has done and found in tunnel 351. Doon explains to Lina what he has seen after he opens the 
mysterious door in the tunnel 351 that is always locked. Lina gets stunned to hear what Doon has found out in the tunnel 351. Lina can hardly believe it all. She feels dizzy, as if she were hit on the head to hear Doon's explanation in detail about the room which is pilled up with food, clothes, boxes, cans, and light bulbs up to the ceiling of the room. One thing that makes Lina more stunned is that when Doon tells her that he sees Mayor Cole falling asleep in the middle of the room with an empty plate in front of him. Doon and Lina come to know that Mayor Cole is the perpetrator of the crisis in the city of Ember. They find out that Mayor Cole all this time has been robbing the citizens of Ember. He is actually a very cunning greedy mayor that has caused the city of Ember to be in a crisis of food.

After the antagonist's greed for power and for food in Jeanne DuPrau's novel The City of Ember is analyzed, it is found that in The City of Ember, Jeanne DuPrau tells about the story of an underground city with a mayor that is very greed for food and for power. Mayor Cole is a very corrupt character who has made use his position for own interesed by exerting power over the townspeople and encouraging them to dedicate to and work hard for the city of Ember that he himself has no need to work hard again. Mayor Cole speaks so glibly to the citizens of the Ember as if he were so care of the city. In fact, what he has done is just for his own interests. In conducting his greed for food, Mayor Cole is helped by Looper and Lizzie Bisco who steal the food supplies from the storeroom and to store them in the tunnel 351. Greed conducted by Mayor Cole is only for his personal interests so that he can enjoy his tenure as mayor, have fun and eat much good food that he is vast, heavy and so big in his stomach. They find out that Mayor Cole all this time has been robbing the citizens of Ember. Mayor Cole's evil deed is revealed in the long run as Doon and Lina find out that Mayor Cole is actually a very cunning greedy mayor and the real perpetrator that has made the city of Ember in a crisis of food.

\section{Conclusion}

Greed is one of the bad manners that draw to various evils and sins. It is selfish excessive or uncontrolled desire for possession or pursuit of money, wealth, food, or other possessions, especially when this denies the same goods to others. It is found in the analysis that Cole is a mayor in the city of Ember who has misused his position as a mayor for his own interests so that he will not need to work hard anymore in taking care the city, and ordered his followers to steal food supplies to satisfy his greed for food. What has been done by Mayor Cole is due to his greed for food and power. Greed is harmful. Mayor Cole's greed has harmed the whole citizens since the food supplies which are supposed to be still sufficient for the citizens of the Ember, become deficient that the citizens are deprived. Anything bad cannot be concealed. Sooner or later, it will be revealed. It is found in the analysis that the evil deed of Mayor Cole who very carefully conceals his cunning, eventually is revealed. Greed is the key to trouble and carries man to hardship. It causes him to commit sin. Mayor Cole's greed ly carries him to hardship, and causes him to speak words full of hogwash as t lis plan run as expected.

\section{References}

Abrams, M. H. 1981. A Glossary of A Literary Term $4^{\text {th }}$ Ed. New York: Holt, Rinehart and Winston. 
Aquinas, Thomas. 1920. a. The Summa Theologica II-II.Q118 (The vices opposed to liberality, and in the first place, of covetousness) (1920, Second and Revised Edition ed.). New Advent. 1920. b. Catechism of the Catholic Church - The Tenth Commandment. Holy See.

Beckson, Karl., Arthur Ganz. 1990. Literary Terms: A Dictionary. Great Britain: Rupa \& Co.

Burleson, B. 1964. Human Behavior. New York: Haricot Bruce and World Inc.

Collins, C. Carter. 1978. A Student's Guide to Literature. New York: Washington Square Press, Inc.

Cuddon. J. A. 1992. Dictionary of Literary Terms and Literary Theory. London: Penguin Books.

Fowler, A. Lastair. 1907. A History of Literature. London : Basil Blackwell Ltd.

Fromm, Erich. 1941. Escape from Freedom (2013 ed.). Open Road Media. ISBN 9781-4804-0201-0. 0200-3.

1956. The Art of Loving (2013 ed.). Open Road Media. ISBN 978-1-4804-

Herbet, Martin. 1990. Planning a Research Project. London: Macmillan.

Krishnananda, Sri Swami. 1989. The Struggle for Perfection. India: The Divine Life Society.

Koul L. 1984. Methodology of Education Research. New Delhi: Vikas Publishing House.

Polit, D. and Hungler, B. 1999 Research, Principles and Methods. Philadephia: Lippincourt.

Setiawan, Muarif, Barus, Efendi, and Pawiro, Mhd. Ali. (2017). Cause and effect of suffering in Sydney Sheldon's "If Tomorrow Comes". Language Literacy: Journal of Linguistics, Literature, and Language Teaching. Volume 1, Number 1, Desember 2017, Pages: 73-96 https://jurnal.uisu.ac.id/index.php/languageliteracy/article/view/247/236 Accessed September 2019.

Sinclair, John. 1987. Collins Cobuild English Language Dictionary. London: William Collins Sons \& Co Ltd.

Wiley, John. 2010. Webster's New World College Dictionary. Ohio: Wiley Publishing, Inc.

Yin. 1989. Application of Case Study Research. SAGE: SAGE Publications Ltd.

Horlick, Nicola. 2009. Greed. UK: Palgrave Macmillan.

Baba, Meher (1967). Discourses. Volume II. San Francisco: Sufism Reoriented. 